\title{
In Memoriam ....
}

Le Bureau de l'Association Internationale de Géodésie et la direction du Bulletin Géodésique ont la tristesse de faire part du décès du

Prof. Dr. Dr. Max KNEISSL

survenu le 15 septembre 1973.

\author{
0 \\ o \\ 0 \\ (Une notice biographique détaillée paraîtra dans un prochain bulletin).
}

